DOI: http://dx.doi.org/10.33846/ghs5314

\title{
Hubungan Ketuban Pecah Dini dengan Kejadian Asfiksia Neonaturum di Puskesmas Perawatan Pelauw Tahun 2019
}

\author{
Arindiah Puspo Windari (koresponden) \\ (D III Kebidanan, STIKes Maluku Husada; arindiah7@gmail.com) \\ Syafitrah Umamity \\ (IImu Keperawatan; STIKes Maluku Husada) \\ Berlin Minaely \\ (DIII Kebidanan; STIKes Maluku Husada)
}

\begin{abstract}
ABSTRAK
Asfiksia neonatorum termasuk dalam bayi baru lahir dengan risiko tinggi karena memiliki kemungkinan lebih besar mengalami kematian bayi atau menjadi sakit berat dalam masa neonatal. Faktor yang menyebabkan asfiksia neonatorum antara lain faktor keadaan ibu, faktor keadaan bayi, faktor plasenta dan faktor persalinan. Penelitian ini bertujuan untuk mengetahui faktor-faktor yang berhubungan dengan kejadian asfiksia neonatorum di Puskesmas Perawatan Pelauw. Jenis penelitian menggunakan penelitian survey analitik, dengan pendekatan cross sectional. Populasi dansampel adalah seluruh ibu yang melahirkan bayi yang mengalami Asfiksia Neonatorum di Puskesmas Perawatan Pelauw pada bulan Januari - Mei 2019 sebanyak 35 orang. Sedangkan kelompok kontrol seluruh ibu yang melahirkan bayi yang tidak mengalami Asfiksia Neonatorum sebanyak 74 orang dengan menggunakan teknik Total sampling. Instrumen penelitian menggunakan kuesioner. Pengolahan data dengan SPSS, menggunakan Uji Chi Square $\left(x^{2}\right)$ dan tingkat kemaknaan 0,05 . Hasil dalam penelitian ini diperoleh untuk semua varibael yang diukur nilai signifikan $(p=0,000)$. Dari hasil tersebut dapat disimpulkan ada hubungan usia ibu, Ketuban Pecah Dini (KPD), berat badan bayi dengan kejadian asfiksia neonatorum di Puskesmas Perawatan Pelauw
\end{abstract}

Kata kunci: ketuban pecah dini; asfiksia neonatorum

\section{PENDAHULUAN}

Derajat kesehatan masyarakat di suatu Negara dapat dinilai dengan beberapa indikator Indikator tersebut pada umumnya tercermin dalam kondisi morbiditas, mortalitas, dan status gizi. Indikator mortalitas digambarkan melalui Angka Kematian Bayi (AKB), Angka Kematian Balita (AKABA), Angka Kematian Ibu (AKI). Bila AKI, AKB, dan AKABA disuatu negara rendah maka pelayanan kesehatan sudah baik di negara tersebut dan sebaliknya bila AKI, AKB, AKABA tinggi maka pelayanan kesehatan di Negara tersebut belum baik. ${ }^{(1)}$

Asfiksia neonatorum merupakan kegawatdaruratan bayi baru lahir berupa depresi pernafasan yang berlanjut sehingga menimbulkan berbagai komplikasi. Disamping itu, Asfiksia neonatorum merupakan penyebab mortalitas dan morbiditas, dan paling sering terjadi pada periode segera setelah lahir dan menimbulkan sebuah kebutuhan resusitasi dan intervensi segera untuk meminimalkan mortalitas dan morbiditas. ${ }^{(2)}$

Salah satu indikator SDGs adalah Angka Kematian Neonatus (AKN) yang merupakan indikator dari tujuan SDGs yang ke tiga yaitu menurunan Angka Kematian Neonatus menjadi 12 per 1.000 kelahiran di tahun 2030.(3)

Laporan World Health Statistic 2014 menyebutkan bahwa angka kematian neonatus pada tahun 2012 di dunia adalah 21 per 1.000 kelahiran hidup. Berdasarkan penelitian World Health Organization (WHO), diseluruh dunia terdapat kematian bayi khususnya neonatus sebesar 10.000.000 per tahun. Laporan WHO juga menyebutkan bahwa AKB kawasan Asia Tenggara merupakan kedua yang paling tinggi yaitu sebesar 142 per 1.000 setelah kawasan Afrika. Di tahun 2011, Indonesia merupakan Negara dengan AKB tertinggi kelima untuk negara ASEAN yaitu 35 per 1.000, dimana Myanmar 48 per 1.000, Laos dan Timor Leste 46 per 1.000, Kamboja 36 per $1.000 .{ }^{(4)}$

Asfiksia neonatorum lahir menempati penyebab kematian bayi ke 3 di dunia dalam periode awal kehidupan. Setiap tahunnya kira-kira 3\% (3,6 juta) dari 120 juta bayi baru lahir mengalami asfiksia, hamper 1 juta bayi ini meninggal. ${ }^{(5)}$

. WHO menyatakan bahwa AKB akibat asfiksia neonatorum di kawasan Asia Tenggara menempati urutan kedua yang paling tinggi yaitu sebesar 142 per 1000 setelah Afrika. Indonesia merupakan negara dengan AKB dengan asfiksia tertinggi kelima untuk negara ASEAN pada tahun 2011 yaitu 35 per 1000, dimana Myanmar 48 per 1000, Laos dan Timor Laste 48 per 1000, Kamboja 36 per $1000 .{ }^{(6)}$ 
Angka Kematian Neonatal (AKN), Angka Kematian Bayi (AKB), dan Angka Kematian Balita (AKABA) merupakan beberapa indikator yang berhubungan dengan status kesehatan anak. Berdasarkan hasil Survei Demografi dan Kesehatan Indonesia (SDKI) tahun 2012, angka Kematian Neonatus (AKN) pada tahun 2012 sebesar 19 per 1.000 kelahiran hidup. Angka ini sama dengan AKN berdasarkan SDKI tahun 2007 dan terdapat penurunan 1 point dibanding SDKI tahun 2002-2003 yaitu 20 per 1.000 kelahiran hidup. Kasus kematian bayi berdasarkan faktor dari bayi, akibat prematur berkontribusi sebanyak 32 kasus $(21,92 \%)$, akibat asfiksia neonatorum berkontribusi sebanyak 46 kasus $(31,51 \%) .(7)$

. Sedangkan berdasarkan data dari Dinas Kesehatan (Dinkes) Provinsi Maluku, AKB yaitu 36 per 1.000 kelahiran hidup dan AKN sebesar 24/1000 kelahiran hidup. ${ }^{(8)}$

Asfiksia neonatorum termasuk dalam bayi baru lahir dengan risiko tinggi karena memiliki kemungkinan lebih besar mengalami kematian bayi atau menjadi sakit berat dalam masa neonatal. Asfiksia adalah keadaan bayi baru lahir tidak dapat bernafas secara spontan dan teratur. Asfiksia atau gagal nafas dapat menyebabkan suplai oksigen ke tubuh menjadi terhambat, jika terlalu lama membuat bayi menjadi koma, walaupun sadar dari koma bayi akan mengalami cacat otak. Kejadian asfiksia jika berlangsung terlalu lama dapat menimbulkan perdarahan otak, kerusakan otak dan kemudian keterlambatan tumbuh kembang.(9)

Faktor yang menyebabkan asfiksia neonatorum antara lain faktor keadaan ibu, faktor keadaan bayi, faktor plasenta dan faktor persalinan. Faktor keadaan ibu meliputi hipertensi pada kehamilan (preeklampsia dan eklampsia) (24\%), perdarahan antepartum (plasenta previa, solusio plasenta) (28\%), anemia dan Kekurangan Energi Kronis (KEK) berkisar kurang dari 10\%, infeksi berat (11\%), dan kehamilan postdate. Faktor keadaan bayi meliputi prematuritas (15\%), BBLR (20\%), kelainan kongenital (1-3\%), ketuban bercampur meconium. ${ }^{(10)}$

\section{METODE}

Jenis penelitian yang digunakan adalah penelitian survey analitik. Desain yang digunakan dalam penelitian ini adalah case control yaitu rancangan penelitian yang membandingkan antara kelompok kasus dengan kelompok kontrol untuk mengetahui proporsi kejadian berdasarkan riwayat ada tidaknya paparan. Rancangan penelitian yaitu dengan pendekatan Retrospective. Pendekatan ini merupakan penelitian yang variabel-variabel bebasnya telah terjadi perlakuan atau treatment tidak dilakukan pada saat penelitian berlangsung, sehingga penelitian ini biasanya dipisahkan dengan penelitian eksperimen. Peneliti ingin melacak kembali, jika dimungkinkan, apa yang menjadi faktor penyebab terjadinya sesuatu. ${ }^{(11)}$ Teknik pengambilan sampel yang digunakan yaitu total sampling. Dimana pemgambilan semua populasi menjadi sampel.

\section{HASIL}

Umur

Untuk artikel penelitian, hasil harus disajikan secara jelas dan ringkas. Usahakan memilih cara penyajian data yang efektif, misalnya berupa tabel dan gambar. Persyaratan penulisan tabel adalah sebagai berikut:

Tabel 1. Distribusi Responden Berdasarkan Umur ibu

\begin{tabular}{|c|c|c|}
\hline Umur Ibu & Jumlah(n) & Persen (\%) \\
\hline <20 Tahun & 14 & 12,8 \\
\hline 20 - 35 Tahun & 74 & 67,9 \\
\hline > 35 Tahun & 21 & 19,3 \\
\hline Jumlah & 109 & 100 \\
\hline
\end{tabular}

Berdasarkan tabel 1 diperoleh karakteristik responden menurut umur yaitu sebagian besar memiliki umur 20-35 tahun sebanyak 74 responden.

Tabel 2. Distribusi Responden Berdasarkan Pendidikan

\begin{tabular}{|c|c|c|}
\hline Pendidikan & Jumlah $(\mathrm{n})$ & Persen (\%) \\
\hline SMA & 87 & 79,8 \\
\hline DIII/SI & 22 & 20,2 \\
\hline Jumlah & 109 & 100 \\
\hline
\end{tabular}


Berdasarkan tabel 2, diperoleh karakteristik responden menurutpendidikan yaitu sebagian besar memiliki tingkat pendidikan SMA sebanyak 87 responden.

Tabel 3. Distribusi Responden Berdasarkan pekerjaan

\begin{tabular}{|c|c|c|}
\hline Pekerjaan & Jumlah $(\mathrm{n})$ & Persen (\%) \\
\hline Tidak Bekerja & 54 & 49,5 \\
\hline PNS & 18 & 16,5 \\
\hline Wiraswasta & 37 & 33,9 \\
\hline Jumlah & 109 & 100 \\
\hline
\end{tabular}

Berdasarkan tabel 3 diperoleh karakteristik responden menurut pekerjaan ibu yaitu sebagian besar tidak bekerja.

Tabel 4. Distribusi Responden Berdasarkan paritas

\begin{tabular}{|c|c|c|}
\hline Paritas & Jumlah (n) & Persen (\%) \\
\hline Primipara & 26 & 23,9 \\
\hline Multipara & 68 & 62,4 \\
\hline Grandemultipara & 15 & 13.8 \\
\hline Jumlah & 109 & 100 \\
\hline
\end{tabular}

Berdasarkan tabel 4, diperoleh karakteristik responden menurut paritas ibu yaitu sebagian besar memiliki paritas multipara sebanyak 68 responden.

Tabel 5. Distribusi Responden Berdasarkan Asfiksia Neonatorum

\begin{tabular}{|c|c|c|}
\hline Asfiksia Neonatorum & Jumlah $(\mathrm{n})$ & Persen $(\%)$ \\
\hline Ya & 35 & 32,1 \\
\hline Tidak & 74 & 67,9 \\
\hline Jumlah & 109 & 100 \\
\hline
\end{tabular}

Berdasarkan tabel 5, dapat digambarkan bahwa klasifikasi kejadian asfiksia neonatorum yaitu sebagian dan sebagian kecil mengalami kejadian asfiksia neonatorum sebanyak 35 responden.

Tabel 6. Distribusi Responden Berdasarkan Usia ibu

\begin{tabular}{|c|c|c|}
\hline Usia Ibu & Jumlah $(\mathrm{n})$ & Persen (\%) \\
\hline Resiko Tinggi & 35 & 32,1 \\
\hline Resiko Rendah & 74 & 67,9 \\
\hline Jumlah & 109 & 100 \\
\hline
\end{tabular}

Berdasarkan tabel 6, dapat digambarkan bahwa klasifikasi usia ibu yaitu sebagian besar mengalami resiko rendah

Tabel 7. Distribusi Responden Berdasarkan Ketuban Pecah

\begin{tabular}{|c|c|c|}
\hline Ketuban Pecah Dini (KPD) & Jumlah $(\mathrm{n})$ & Persen (\%) \\
\hline Ya & 51 & 46.8 \\
\hline Tidak & 58 & 53.2 \\
\hline Jumlah & 109 & 100 \\
\hline
\end{tabular}

Berdasarkan tabel 7, dapat digambarkan bahwa klasifikasi kejadian Ketuban Pecah Dini (KPD) yaitu sebagian besar tidak mengalami Ketuban Pecah Dini (KPD)

Tabel 8. Hubungan Ketuban Pecah Dini

\begin{tabular}{|c|c|c|c|c|c|c|c|}
\hline \multirow{2}{*}{ KPD } & \multicolumn{3}{|c|}{ Asfiksia Neonatorium } & \multicolumn{2}{c|}{ Total } & $p$-value \\
\cline { 2 - 6 } & \multicolumn{2}{|c|}{ Ya } & \multicolumn{2}{|c|}{ Tidak } & \multirow{2}{*}{} & \\
\cline { 2 - 6 } & $\mathrm{n}$ & $\%$ & $\mathrm{n}$ & $\%$ & $\mathrm{n}$ & $\%$ & \multirow{2}{*}{0,000} \\
\hline Ya & 35 & 32,1 & 16 & 14,7 & 51 & 46,8 & \\
\hline Tidak & 0 & 0 & 58 & 53,2 & 58 & 53,2 & \\
\hline Total & 35 & 32,1 & 74 & 67,9 & 109 & 100 & \\
\hline
\end{tabular}


Berdasarkan hasil pengolahan data dengan menggunakan uji Chi-Square diperoleh nilai signifikasi sebesar 0,000 , dapat disimpulkan bahwa $\mathrm{HO}$ ditolak dan $\mathrm{Ha}$ diterima atau hipotesis penelitian diterima. Artinya ada hubungan Ketuban Pecah Dini (KPD) dengan kejadian asfiksia neonatorum di Puskesmas Perawatan Pelauw

\section{PEMBAHASAN}

Hasil frekuensi karakteristik responden menurut umur yaitu sebagian besar memiliki umur 2035 tahun sebanyak 74 responden $(67,9 \%)$, sebagian kecil memiliki umur $<20$ tahun sebanyak 14 responden (12,8\%), dan 21 responden memiliki umur > 35 tahun sebayak 21 responden $(19,3 \%)$ (5\%).

Wanita yang berumur $>35$ dan $<20$ tahun dapat meningkat risiko terjadi masalah-masalah komplikasi selama kehamilan dan persalinan. Pada umur kurang dari 20 tahun, organ-organ reproduksi belum berfungsi dengan sempurna, sehingga bila terjadi kehamilan dan persalinan akan mudah mengalami komplikasi. Selain itu, kekuatan otot-otot perineum dan otot-otot perut belum bekerja secara optimal. ${ }^{(12)}$

Hasil distribusi responden dapat digambarkan bahwa klasifikasi usia ibu yaitu sebagian besar mengalami resiko rendah sebanyak 74 responden $(67,9 \%)$, dan sebagian kecil mengalami resiko tinggi sebanyak 35 responden $(32,1 \%)$.

Reproduksi sehat dikenal dengan usia yang aman untuk kehamilan adalah wanita dengan usia 20-35 tahun. Usia 20-35 tahun adalah relative paling aman dari segi reproduksi sehat di mana seorang ibu bisa mengandung dengan aman apabila mendapat pemeliharaan yang baik selama mengandung. Usia ibu merupakan faktor yang berhubungan dengan kejadian asfiksia neonatorum. Klasifikasi kejadian asfiksia neonatorum yaitu sebagian besar tidak mengalami kejadian asfiksia neonatorum sebanyak 74 responden $(67,9 \%)$, dan sebagian kecil mengalami kejadian asfiksia neonatorum sebanyak 35 responden $(32,1 \%)$.

Salah satu faktor persalinan yang dapat menyebabkan kejadian asfiksia neonatorum yaitu Ketuban Pecah Kini (KPD) (Mochtar, 2010).Ketuban Pecah Dini (KPD), yaitu pecah ketuban 6 jam atau lebih sebelum kelahiran. Komplikasi yang dapat terjadi pada janin dengan ketuban pecah dini yaitu prematuritas, infeksi, malpresentasi, prolapsus funikuli, dan mortalitas perinatal. Kedua jenis komplikasi tersebut dapat berakibat terjadinya asfiksia. Tempat yang paling sering terinfeksi adalah alat-alat respirasi. ${ }^{(13)}$

Berat badan lahir dibagi dua, yaitu berat badan lahir normal (2500 - 4000 gram) dan berat badan lahir rendah (BBLR) (<2500 gram). Berat badan lahir rendah mempunyai masalah antara lain : pusat pengaturan pernafasan dan alat pencernaannya belum sempurna, kemampuan metabolisme panas masih rendah sehingga berakibat terjadinya asfiksia, asidosis, dan mudah terinfeksi. ${ }^{(14)}$

\section{Hubungan Ketuban Pecah Dini dengan kejadian Asfiksia Neonaturum}

Hasil penelitian yang dilakukan di Puskesmas Perawatan Pelauw dengan menggunakan uji Chi-Square berdasarkan hubungan Ketuban Pecah Dini (KPD) dengan kejadian asfiksia neonatorum diperoleh nilai signifikasi sebesar 0,000 atau $\rho=0,000$ yang lebih kecil dari $0,05 \%$ sehingga dapat disimpulkan bahwa $\mathrm{H} 0$ ditolak dan Ha diterima atau hipotesis penelitian diterima. Artinya ada hubungan Ketuban Pecah Dini (KPD) dengan kejadian asfiksia neonatorum di Puskesmas Perawatan Pelauw.

Ketuban Pecah Dini (KPD) akan menyebabkan kelahiran bayi asfiksia neonatorum bila disertai dengan penyulit lainnya. Hal ini disebabkan oleh hipoksia janin dalam uterus dan hipoksia ini berhubungan dengan faktor-faktor yang timbul dalam kehamilan, persalinan, atau segera setelah bayi lahir. Dengan pecahnya ketuban terjadi oligohidroamnion yang menekan tali pusat hingga terjadi asfiksia atau hipoksia. Terdapat hubungan antara terjadinya gawat janin dan derajat hidroamnnion, semakin sedikit air ketuban, janin semakin gawat .(15)

Hasil penelitian ini sama dengan hasil penelitian yang dilakukan tentang hubungan antara ketuban pecah dini dan kejadian asfiksia pada bayi baru lahir di Ruang Ponek Bapelkes RSD Jombang, dimana terdapat hubungan antara Ketuban pecah dini dengan kejadian asfiksia pada bayi baru lahir. Hasil penelitian ini juga sesuai dengan hasil penelitian yang menyatakan ada hubungan antara ketuban pecah dini dengan kejadian asfiksia neonatorum di RSUD Gunung Sitoli. Menurut asumsi peneliti, terdapat kesesuaian antara ibu yang didiagnosa ketuban pecah dini dengan kejadian asfiksia neonatorum. Dimana ibu yang mengalami ketuban pecah dini (KPD) pada kelompok kasus/ekperimen sebanyak 35 responden $(32,1 \%)$ bayinya mengalami asfiksia neonatorum setelah melahirkan. Sedangkan kelompok kontrol yang mengalami ketuban pecah dini (KPD) sebanyak 16 
responden $(14,7 \%)$, hal ini bisa dikarenakan komplikasi yang dialami ibu selama kehamilan seperti anemia di waktu hamil sehingga bayi yang di lahirkan mengalami proses pertumbuhan janin didalam masa kehamilan terganggu dan mengakibatkan keadaan janin yang mengkawatirkan setelah persalinan seperti BBLR, Asfiksia neonatorum, sindroma gawat nafas dan lain sebagainya.

\section{KESIMPULAN}

Ada hubungan Ketuban Pecah Dini dengan kejadian asfiksia neonatorum di Puskesmas Perawatan Pelauw Kecamatan Pulau Haruku Kabupaten Maluku Tengah.

\section{DAFTAR PUSTAKA}

1. Depkes RI. 2014. Profil Kesehatan Indonesia. Jakarta: Departemen Kesehatan Republik Indonesia; 2014.

2. Anik Maryunani. dkk. 2013. Asuhan Kegawatdaruratan Maternal \& Neonatal. Jakarta: Trans Info Media.

3. Kementrian Kesehatan Republik Indonesia. 2015. Profil Kesehatan Indonesia. Jakarta.

4. Syaiful, Y \& Khudzaifah, U. (2016). Faktor yang berhubungan dengan kejadian asfiksia neonatorum di RS Muhammadiyah Gresik. Journals of Ners Community.

5. Hanifa Wiknjosastro. 2008. Ilmu Kandungan. Edisi 2. EGC: Jakarta.

6. Anik Maryunani. 2013. Asuhan Kegawatdaruratan Maternal \& Neonatal. Jakarta: Trans Info Media.

7. Hartiningrum, CY., 2014, Gambaran Penyebab Kematian Bayi di RSUD Banjar Provinsi Jawa Barat, Jurnal IBI JABAR.

8. Dinas Kesehatan Provinsi Maluku 2011. Profil Kesehatan Maluku. https://pusdatin.kemkes.go.id/resources/download/profil/PROFIL_KES_PROVINSI_2012/30_Prof il_Kes.Prov.Maluku_2012.pdf

9. Kementrian Kesehatan Republik Indonesia 2013. Profil Kesehatan Indonesia. Jakarta

10. Mochtar, Rustam. 2010. Sinopsis Obstetri. Jakarta: EGC

11. Notoatmodjo. 2012. Metode Penelitian Kesehatan. Jakarta : Rineka Cipta

12. Revrelly. Hubungan Umur Ibu Dengan Kejadian Asfiksia Neonatorum. 2011.

13. Rahma, A \& Armah, M., 2014, Analisis Faktor Risiko Kejadian Asfiksia Pada Bayi Baru Lahir di RSUD Syekh Yusuf Gowa dan RSUP DR Wahidin Sudirohusodo Makassar Tahun 2013, Jurnal Kesehatan, p. 283.

14. Katiandagho, N \& Kusmiyati. (2015). Faktor-faktor yang berhubungan dengan kejadian asfiksia neonatorum. Jurnal IImiah Bidan

15. Prawirohardjo, Sarwono. 2012. Ilmu Kebidanan Cetakan Ketiga. Jakarta: PT Bina Pustaka Sarwono Prawirohardjo 